\title{
Online közösség vagy offline magány - egy város a jövőből: Netville
}

\section{Szerzői információ:}

Bartha Zoltán:

1977-ben született Marosvásárhelyen; késôbb Magyarországra költözött. 2000-ben végezett a Miskolci Egyetemen, a Gazdaságtudományi Kar gazdálkodási szakán, közvetlenül az egyetem befejezése után, doktoranduszként a Miskolci Egyetem Világgazdaságtani és Összehasonlító Gazdaságtani Tanszékére került. Jelenleg, a $\mathrm{PhD}$. program keretében, a transznacionális vállalatok tudásmenedzsmentjében megfigyelhetố sajátosságok elemzésével foglalkozik, korábban a digitális városok gazdasági vizsgálatát kutatta.

Így hivatkozzon erre a cikkre:

Bartha Zoltán. „Online közösség vagy offline magány - egy város a jövőből: Netville”. Információs Társadalom II, 1. szám (2002): 68-74.

$\Longrightarrow$ https://dx.doi.org/10.22503/inftars.II.2002.1.5 $\rightleftharpoons$

A folyóiratban közölt müvek

a Creative Commons Nevezd meg! - Ne add el! - Így add tovább! 4.0 


\section{Online közösség vagy offline magány - egy város a jövôből: Netville}

Régóta tart a vita, hogy a társadalmi és technológiai innovációk milyen hatást gyakorolnak a közösségekre. Számos szerzố jutott arra a következtetésre, hogy az elszaporodó fenyegető jelenségek (társadalmi deviancia, bűnözés, népszaporulat csökkenése stb.) elsôdleges oka a hagyományos közösség felbomlása. Durkheim a fokozódó munkamegosztást, Tönnies a megerôsödô kapitalizmust, Milgram az urbanizációt kárhoztatta a közös magatartási normákon, hiteken és érzéseken alapuló közösségek felbomlásáért. Megítélésük szerint az említett modernizációs folyamatok eredményeként elóállt személytelen és individualista társadalom a nyugati világ hanyatlását mutatja. Mások arra hívták fel a figyelmet, hogy a közösségek nem szűntek meg, csupán megváltoztak, mégpedig azért, mert megváltozott a szerveződési alapjuk. Míg a hagyományos közösségek területi elven szerveződtek, addig - amint arra Fisher szubkulturális elméletében utal - a modern közösségek alapja a közös érdeklődés és értékválasztás. A területileg integrált kapcsolatok helyét tehát a közös érdeklődésre alapozott, területileg szétszórt kapcsolatok hálózatai veszik át. Az olyan technológiai innovációk, mint a számítógépes kommunikáció - érvel a másik oldal - elősegítik a kapcsolati hálózatok kialakulását, és így hozzájárulnak az új közösségek megerősödéséhez.

Hampton dolgozatábạn azt vizsgálja, hogy milyen hatással van a közösségekre a személyi számítógépek és az Internet elterjedése. Azt a feltételezést akarja igazolni, hogy a számítógépes kommunikáció hozzájárul a társadalmi tôke növekedéséhez, mert növeli a közösségi életben való részvételt és segíti a társadalmi hálózatok kialakulását. Ily módon a szerzô is állást foglal a fenti vitában, és inkább azokkal ért egyet, akik hasznosnak, és nem kártékonynak tartják a modern technológiát.

\section{Kulcsfogalmak}

A közösségek vizsgálatánál a legtöbb szerzônél központi szerepet kap a társadalmi tőke. Hampton is nagy jelentőséget tulajdonít neki, ugyanakkor különbséget tesz kötelékes és hálózati társadalmi tôke között. Kötelékes társadalmi tôke alatt azokat az együttmúködési normákat és közös viselkedési szabályokat érti, amelyek elősegítik a csoportkohéziót és hozzájárulnak a közösségen belüli szoros kapcsolat kialakulásához. Nézete szerint a hagyományos, területi elven szerveződő közösségek híveire ez a kapcsolati forma jellemzô. A hálózati társadalmi tôke ezzel szemben a hálózati közösségek kapcsolatait magyarázza, definíciója szerint a társadalmi hálózatok tagjai között létesülő segítségnyújtási, információs és baráti kapcsolatok összessége. Hampton ezt a definíciót részesíti elốnyben, és a késôbbiekben, ha társadalmi tôkérôl beszél, akkor hálózati társadalmi tôkét kell alatta értenünk. 
Amint az előbb elmondottakból is látható, Hampton is (l. még: Fischer, 1975) azt a nézetet vallja, hogy a modern társadalomban az emberek nem területi elven szerveződő csoportokhoz, hanem hálózatokhoz tartoznak. A közösség ebben a felfogásban a különböző erősségű társadalmi kötelékekből álló, a hagyományos határokon átnyúló, és különböző társadalmi keretek között létezố támogató kapcsolatok hálózata. Ezt a kapcsolati hálót a társadalmi tôkével írhatjuk le. A közösséget az egyes személyek közötti kapcsolatok együttese adja, viszont a kapcsolat minőségét, a „közösség erejét”, a társadalmi tőke írja le. Annál erôsebb egy közösség, minél több társadalmi tốkét hordoz. A pótlólagos társadalmi tôke létrehozása az új társadalmi kötelékek létrehozási, megtartási és megerősítési képességétôl függ. Ezt a képességet a számítógépes kommunikáció javíthatja.

A számítógépes kommunikáció sajátosságából fakad, hogy alkalmas mind a helyi, mind a távoli kapcsolatok építésére. A két köteléktípus együttesét, a helyi és a távoli kapcsolatok összességét, mégpedig azokat, amelyeket a számítógépes kommunikáció segít elő, Hampton glokalizációnak nevezi. Ebben a fogalmi keretben a glokalizáció alapvetố szerepet játszhat az új, hálózati közösségek megerôsödésében.

\section{Elözmények}

A közösségekről, a társadalmi tókéról és az új technikai vívmányokról szóló vitát alaposan megélénkítette Putnam, aki egy 2000-ben kiadott összefoglaló tanulmányában rámutatott, hogy a XX. század utolsó harmadában érzékelhetően csökkent a társadalmi tôke az Egyesült Államokban. Ennek okaként két tényezốt jelölt meg: a generációváltást, illetve egy új technikai vívmány, a televízió elterjedését. A televízió hozzájárult a szabadidôs tevékenységek individualizálásához, elszakította az egyént a közösségtől és otthon-centrikussá tette az emberek életét. Többen hasonló szerepet tulajdonítanak a számítógépnek és az Internetnek is (Kraut és társai, Nie és Erbing), mások viszont a számítógépes kommunikáció közösségteremtố erejét hangsúlyozzák (Rainie, Cole). Erról részletesebben lásd Molnár Szilárd Információs társadalom és a társadalmi kapcsolatok csoportszintû tôkéjének válsága címú cikkét az Információs Társadalom folyóirat 2001/1. számában

\section{A felmérés körülményei}

Hampton célja az volt, hogy bebizonyítsa, hogy a (szélessávú) számítógépes kommunikáció jótékonyan hat a társadalmi tôke növekedésére, ezáltal elősegíti a helyi és a távolsági kapcsolatok létrejöttét, illetve elmélyülését, azaz a számítógépes kommunikáció közösségteremtố és - megtartó erôvel bír. A vizsgálat terepéül Netvillet választotta, egy kísérleti lakókörzetet Toronto elővárosában. 1996-ban több számítástechnikai és telekommunikációs cég elhatározta, hogy egy közös, nem profitorientált vállalkozás keretében egy teljesen behálózott, szélessávú elérést biztosító (10 Mbps), korszerú multimédiás szolgáltatásokat kínáló lakónegyedet hoznak létre. Ennek eredményeként épült fel Netville, amely 109 lakásából 64-et kötöttek rá a helyi szélessávú hálózatra, és az ott lakóknak Internet hozzáférést, helyi videofon elérést, elektronikus zenei, egészségügyi, banki, kereskedelmi, könyvtári szolgáltatáso- 
kat kínáltak ingyen. A projekt finanszírozói késôbb elfordultak a programtól, így az addigi ingyenes szolgáltatásokat 1999-ben megszűntették, és ennek tudható be az is, hogy 45 háztartást soha nem kapcsoltak rá a hálózatra.

A szerzô beköltözött Netville egyik lakásába, személyesen részt vett a közösség számos összejövetelén, és nyomon követte a közösen kezdeményezett akcióikat. Így a dolgozat egy részét a közösség etnográfiai vizsgálatából származó adatok teszik ki. De a meghatározó szerepet a statisztikai módszerek játsszák. Igen részletes kérdőíves felmérést végeztek, személyes kikérdezést alkalmazva számítógépes segédlettel, amely során a körzet valamennyi háztartásának egy-egy felnốtt tagját felkeresték. Az elképzelés az volt, hogy a behálózott és hagyományos háztartásokat összehasonlítva mutatnak rá a szélessávú számítógépes kommunikáció sajátosságaira. Végül a háztartások 62\%-tól sikerült értékelhető adatokat begyújteni.

Netville-i kiválasztásának, valamint az alkalmazott módszernek számos elônye van. Mivel egy helyen lehetett megfigyelni a behálózott és hagyományos háztartásokat, ráadásul, mivel kezdetben az építtetô mindenkinek megígérte a kapcsolatot, így teljesen véletlenszerúen alakult, hogy végül kinek állt rendelkezésre a szolgáltatás, és kinek nem, ez kiváló lehetôséget kínált az objektív összehasonlításra. A sokoldalú statisztikai elemzés több új elemre világított rá. Ugyanakkor a szabályos mintavétel hiánya aggodalomra adhat okot. Ezeket az aggodalmakat a szerzố azzal igyekezett oldani, hogy egy részletes elemzést végzett, amelyben kimutatta, hogy az egyetlen tényezô, amelyben a beköltözöttek szignifikánsan különböznek a kanadai átlagnépességtől, a jövedelmi viszony: a beköltözöttek átlagjövedelme a kanadai magas jövedelmúek átlagának felelt meg. Ezen kívül a szerzố saját megfigyeléseire hivatkozva azt állítja, hogy a kérdőívre értékelhetô választ adók, illetve a nem válaszolók között nincs olyan különbség, ami torzítaná az eredményeket. Ezt természetesen aligha lehet ellenőrizni

\section{Eredmények}

Hampton vizsgálódásai és eredményei három részre oszthatóak. Egyrészt megvizsgálta a szélessávú számítógépes kommunikáció hatását a távolabbi kapcsolatokra, másrészt a helyi kapcsolatokra, végül pedig a helyi közéleti aktivitásra gyakorolt hatásukat. Az elsố kettô esetében elsősorban statisztikai módszereket alkalmazott (regressziószámítást, illetve az eredmények tesztelésére hipotézisvizsgálatokat), az utóbbinál pedig fóleg etnográfiai, leíró jellegû́ módszereket.

\section{Távoli kapcsolatok és a számítógépes kommunikáció}

Általános meggyőződés szerint a számítógépes kommunikáció elsősorban a távolabbi kapcsolatokra van jótékony hatással. A távolság növekedésével a személyes kapcsolatoknak idő- és költségkorlátai vannak. Telefonos kapcsolat esetén az idôkorlát eltűnik, viszont a távolsági hívások költsége továbbra is jelentős akadályt jelent. Számítógépes kommunikációt alkalmazva mind az idő-, mind a költségkorlátoktól megszabadulhatunk, ezért jogosan feltételezhetjük, hogy ez a kommunikációs mód kedvez a leginkább a távolabbi kapcsolatoknak. Ezen túlmenően, a hálózati közösségek eseté- 
ben is ezeknek a kötelékeknek van a legnagyobb szerepe (mivel az azonos érdeklődési körrel rendelkezók hálózatai nem korlátozódnak a közvetlen lakókörzetre), szemben a hagyományos szemlélettel, amely a helyi kapcsolatokat tekinti elsődlegesnek. A kérdés vizsgálata tehát rendkívül fontos.

A felmérés kérdései a kapcsolatok két típusára vonatkoztak. Egyrészt vizsgálták a kölcsönös segítségnyújtás, támogatás intenzitását, másrészt felmérték a társadalmi kapcsolatok alakulását. A kölcsönös segítségnyújtást és a kapcsolatokat a rokonok és a barátok esetében vették számításba, a kapcsolatokat a távolság alapján három csoportba sorolták: 50 kilométeren belüli, 50 és 500 kilométer közti és 500 kilométernél távolabbi. A kérdések arra vonatkoztak, hogy a megkérdezettek érzékeltek-e változást az imént felsorolt kapcsolataikban a Netvillebe való költözést követően. A változásokat egy ötfokozatú skálán lehetett értékelni (erôteljesen romlott, romlott, nem változott, javult, jelentôsen javult). A magyarázó változók között a behálózott-nem behálózott változó mellett még figyelembe vették az életkort, a nemet, a képzettséget, és a beköltözés óta eltelt időt.

1. ábra: A közepes távolságú (50-500 km), kölcsönös segítségnyújtási kapcsolatokban érzékelt változás.

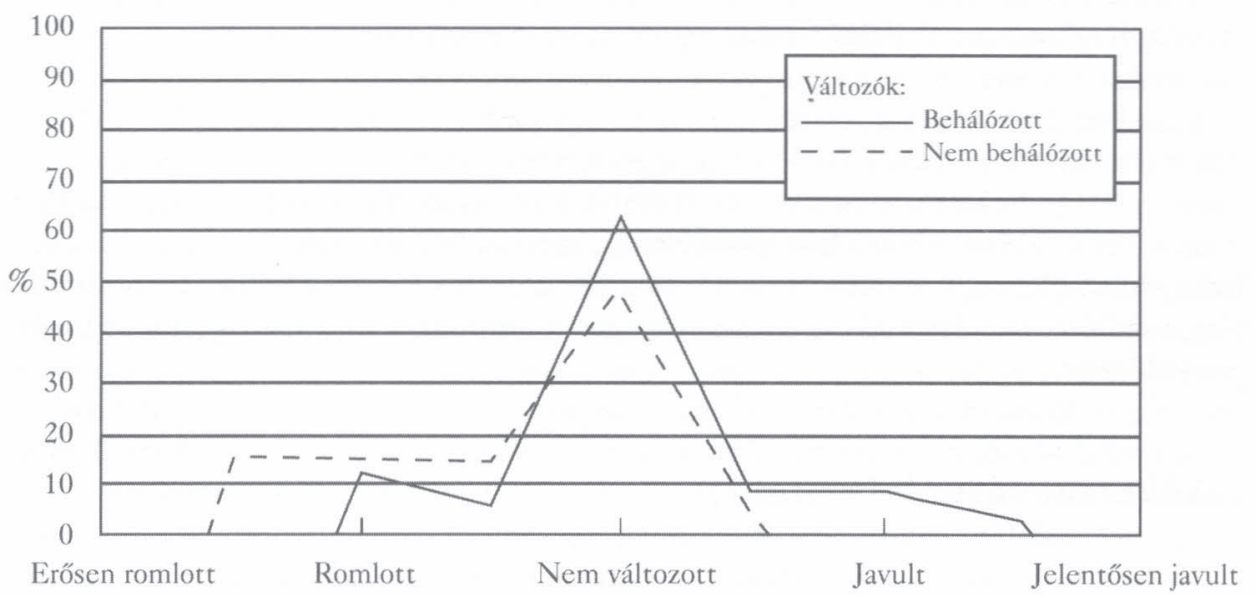

Négy hipotézist fogalmaz meg a szerzô, ezekbôl hármat igazol is, egyet pedig elvet. Az elsố szerint az ingyenes, 24 órás elérést biztosító szélessávú kapcsolat növeli a társadalmi kapcsolatok intenzitását. A kapott eredmények ezt alátámasztják. A behálózott háztartások 67,6 \%-a számolt be változatlanságról vagy erôsödésrốl társadalmi kapcsolataik szintjében, míg a nem behálózottaknál csupán 45\%. Igaz, hogy a behálózottság mellett a kapcsolati intenzitást az életkor és a képzettség is szignifikánsan befolyásolja, valamint a netville-i esetben sajátosan az állapítható meg, hogy míg a szélessávú hozzáférés nélküli háztartások esetében visszaesés tapasztalható a társadalmi kapcsolatok intenzitásában, addig a behálózott háztartások esetén inkább a változatlanság jellemzó, amit az elköltözés ténye magyaráz, de a hipotézis ettôl még elfogadható. Elveti viszont az a feltevését, hogy minél távolabbi egy társadalmi kapcsolat, annál jelentôsebb a kapcsolati intenzitás növekedése a szélessávú számítógépes kommunikáció használatánál. 
2. ábra: A közepes távolságú (50-500 km), kölcsönös segítségnyújtási kapcsolatokban érzékelt változás.

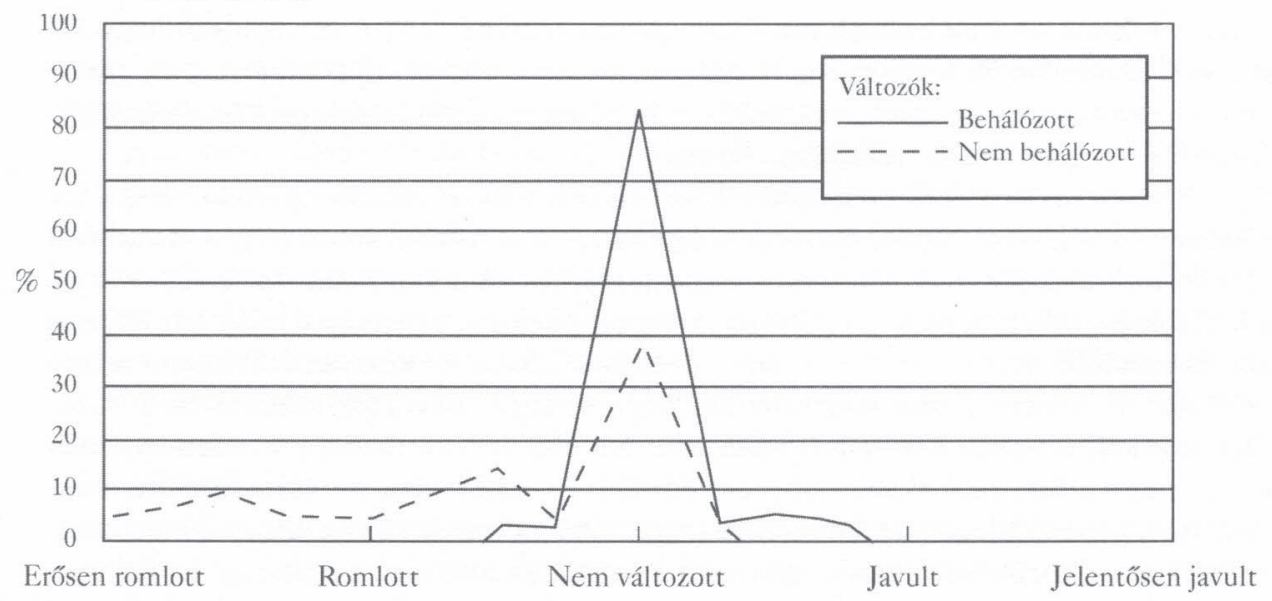

Harmadik hipotézise szerint a kölcsönös segítségnyújtási kapcsolatok intenzitásában még a társadalmi kapcsolatokénál is erôteljesebb növekedés érhetô el a szélessávú kommunikáció révén. Amint a felmérésból kiderült, a társadalmi kapcsolatok alakulásában már a behálózottság az egyetlen magyarázó változó, szemben az iménti három determinálóval, tehát a hipotézis elfogadható. A beköltözést követôen a behálózott lakók 79\%-a nem érzékelt változást, vagy pedig erôsödést tapasztalt a kölcsönös segítségnyújtási kapcsolataiban, a nem behálózottaknál ez az arány csupán $50 \%$. Végezetül egy érdekes jelenségre derít fényt a vizsgálat: a szélessávú számítógépes kommunikáció elsősorban a közepes távolságú (50 és 500 kilométer közötti) kapcsolatok elmélyülésének kedvez Ez tehát az a kör, amelyek létrehozásában, megtartásában, valamint elmélyítésében a számítógépes kommunikáció a legnagyobb segítségünkre lehet.

\section{Lakókörzet társadalmi tőkéje}

Korábbi kutatások kimutatták, hogy amennyiben egy lakókörnyezetben sok lehetôség van a társadalmi interakcióra, az kedvez a társadalmi tốke képzôdésének (Brunson, Kuo és Sullivan). A modern építészet ezért törekszik közösségi terek kialakítására, de a számítógépes kommunikációs is egy ilyen közös, az interakcióra lehetőséget teremtố csatorna lehet.

Akárcsak az elóbbi vizsgálatnál, itt is figyelembe vették a hálózati kapcsolat mellett a nemet, az életkort, a képzettséget és a beköltözés óta eltelt időt. A megkérdezettek kaptak egy listát, amelyen az összes lakókörzetükben élő felnôtt szerepelt, és nyilatkozniuk kellett, hogy kiket ismernek fel a nevük alapján, kikkel szoktak rendszeresen beszélgetni (személyesen, telefonon, vagy e-mailen), és kiket láttak vendégül az elmúlt fél év során. Ismételten a behálózott és nem behálózott háztartások adatainak összehasonlításán alapul a vizsgálat. A vizsgálatok megerôsítették, hogy egy behálózott lakókörzetben a lakók intenzívebben vesznek részt a közéletben. Átlagosan háromszor annyi társuk nevét ismerték fel, kétszer annyival beszéltek, és 50\%-al többet láttak vendégül a behálózott lakók, mint a nem behálózottak. Beigazo- 
1. táblázat: A behálózott és nem behálózott lakosok helyi kötelékei átlagos számának összehasonlítása.

\begin{tabular}{l|l|cc} 
& & \multicolumn{1}{c}{ Átlag } & Std. Dev. \\
\hline \multirow{2}{*}{ Ismeri a nevét } & Behálózott & $25.2 .^{000}$ & 18.8 \\
\cline { 2 - 4 } & Nem behálózott & $8.4 .^{.00}$ & 4.6 \\
\hline \multirow{2}{*}{ Rendszeresen beszélget vele } & Behálózott & $6.4 .^{061}$ & 7.2 \\
\cline { 2 - 4 } & Nem behálózott & $3.2 .^{061}$ & 2.9 \\
\hline \multirow{2}{*}{$\begin{array}{l}\text { Meglátogatta az elmúlt } 6 \\
\text { hónap során }\end{array}$} & Behálózott & $4.8 .^{147}$ & 4.5 \\
\cline { 2 - 4 } & Nem behálózott & $3.2 .^{147}$ & 3.1
\end{tabular}

A kiteröben p-értékek szerepelnek (ANOVA)

(N: Beháló:ott: 36 - Nem behálósott: 20)

Std. Dev. = standard deviation - átlagos eltérés

lódott az a hipotézis is, hogy a behálózott háztartásokban élôknek több, változó mélységú kapcsolatuk van a lakókörzeten belül, illetve az, hogy az ô kapcsolati hálójuk lényegesen sưrúbb, mint a nem kapcsolódottaké. A kapcsolati háló sưrűségét a ténylegesen kialakult, és az adott lakókörzetben maximálisan lehetséges kapcsolatok hányadosaként definiálja a szerzô. A felmérés alapján az is igazoltnak tủnik, hogy a számítógépes kommunikáció nem veszi át a többi kommunikációs forma szerepét, hanem egy új csatornaként társul a már meglévőkhöz. A számítógépes kapcsolattal rendelkezốk átlagosan ötször olyan gyakran beszéltek telefonon a lakókörzetbeli társaikkal, mint a nem behálózott szomszédaik. A szélessávú számítógépes kommunikáció nemcsak több kapcsolat kialakításának kedvez, hanem abban is segít, hogy egyszerre több emberrel tartsunk fenn aktív, tehát rendszeres kommunikáción alapuló kapcsolatot.

A fenti feltételezéseket alátámasztó regressziós függvényekben a behálózottság, mint magyarázó változó mindig megjelent. Mellette viszont gyakran a beköltözés óta eltelt idố is szignifikáns szerepet játszott. Ez teljesen érthetô, hiszen bizonyos idốre szükség van ahhoz, hogy az új lakók beilleszkedjenek a környezetükbe, új ismeretségekre tegyenek szert. Gyakorlatilag azt mondhatjuk, hogy egy behálózott lakókörzetben a számítógépes kommunikáció abban segít, hogy az új lakók sokkal hamarabb be tudjanak illeszkedni. Ne feledjük ugyanakkor, hogy mindezek a kedvezó közösségi hatások azzal a feltétellel érvényesülnek, hogy a teljes körzet rendelkezik számítógépes kapcsolattal, és létezik egy közös, virtuális fórum, ahol a lakók kommunikálhatnak egymással. Netville-ben a fórum szerepét a közös levelezôlista töltötte be.

\section{Összehangolt fellépés}

Hampton két esetet említ, amikor a lakók közösen, összehangoltan léptek fel, közös érdekeik védelmében. Elốször az építési hiányosságok, a lakásokkal kapcsolatos elégtelenségek miatt, késốbb az ingyenes számítógépes szolgáltatások leállításakor került sor közös fellépésre. Mindkét esetben nagy szerepet játszott a körzeti számítógépes kommunikációs hálózat. A levelezôlista segítségével sokkal könnyebben meg lehetett szervezni a tiltakozókat, lényegesen kevesebb idốt kellett fordítani az agitációra, és az információáramlás is sokkal gördülékenyebb volt. Az építővállalat elleni fellépésben igen sikeresek voltak a lakók, a vállalatra nagy nyomás nehezedett (ez részben annak is köszönhetố, hogy a projekt iránt a kezdetektôl fogva élénken érdeklődött a média), és így gyorsan engedményekre kényszerült. Amikor viszont az ingyenes számítógépes hálózat üzemeltetôje bejelentette a szolgáltatások visszavoná- 
sát, a gyors akciókkal semmire sem mentek a lakók. A cég nem engedett, és hamarosan kiderült a virtuális szervezkedés gyengéje is: igazi vezéregyéniség hiányában egy idő után kifulladtak a tiltakozások, a lakók úgy érezték, hogy egyedül maradtak, s a lakóközösségbeli társaik nem igazán támogatják ốket.

\section{Összegzés}

Hampton elveti a közösségek hagyományos értelmezését, helyette az individuális, hálózati közösségek és a számítógépes kommunikáció kölcsönhatását vizsgálja. Érvelésében átveszi azt az elméletet, mely szerint a számítógépes kommunikáció csökkenti a távolabbi kapcsolatok idő- és költségigényét, és bizonyítja, hogy a számítógépes kommunikáció nem veszi át a többi kommunikációs forma szerepét, hanem új csatornaként kapcsolódik a meglévốkhöz.

Az a megoldás, hogy egy újonnan létesült lakókörzetet vizsgál, bizonyos esetekben szerencsétlenül befolyásolta a felmérések eredményeit. Így nem csak a behálózott és kapcsolat nélküli háztartások közötti eltérések hatását mérte, hanem azokat a jelenségeket is, amelyek az új lakókörnyezetből és a költözésból származtak. Fontos megjegyezni, hogy a helyi kapcsolatok és akciók esetén döntô jelentősége volt a körzeti levelezőlistának, illetve annak a ténynek, hogy azt a lakók többsége olvasta. Már meglévô lakókörzetekben meglehetôsen nehéz lenne ezt a helyzetet reprodukálni. A kísérleti jelleg és a teljesen új lakóközösség fontos szerepet játszhatott a történtekben. A projekt az átlagosnál lényegesen nagyobb médiafigyelmet kapott, ami befolyásolhatta az események lefolyását. Arról sem szabad megfeledkezni, hogy itt egy teljesen új helyi közösség formálódását kọvethettük nyomon. Kérdéses, hogy egy már létező közösségre milyen hatást gyakorol egy ilyen számítógépes kommunikációs megoldás.

Mindezek ellenére a dolgozat nagy érdeme, hogy bizonyítékokat szolgáltat a számítógépes kapcsolat közösségteremtő hatására. Megmutatja, hogy hozzájárul a távolabbi kapcsolatok elmélyítéséhez, és segíti az élénkebb közösségi részvételt. Ezáltal fontos érvként szolgálhat a technológiai innovációk közösségekre gyakorolt hatásáról szóló vitákban.

\section{IRODALOM}

Keith N. Hampton (2001): Living The Wired Life in The Wired Suburb: Netville, Glocalization and Civil Society; Doctoral Dissertation (http://web.mit.edu/knh/www/downloads/khampton01.pdf) 